\title{
Effectiveness of Development Strategy in building Optimism and Positive Thinking and Their Relationship of Reducing Future anxiety For students of Home Economics at the Faculty of Specific Education, Alexandria University
}

\section{Dr Hala Said Abo Elela}

Assistant Professor of Curriculum and Methods of Teaching Home Economics

Faculty of Specific Education-Alexandria University

\section{Abstract:}

7 he study aimed to identify the Effective and positive thinking and their relationship to reducing Future anxiety For students of Home Economics at the Faculty of Specific Education, Alexandria University, where he met the concept of optimism and pessimism large turnout among researchers at the present time what revealed by many studies the impact that can be practiced characteristic optimism and high pessimism on the lives of individuals and their performance and the rate of their production. And followed in this study, the experimental design ever per experimental group, And it amounted to sample all the students parameters second year the Department of Home Economics at the Faculty of Specific Education, Alexandria University, and their number (30), a student, for the academic year 2015/2016. The study was the use of tools (optimism and pessimism for Seligman scale, test positive thinking, and the measure of future anxiety.

The study found:

1. There are no significant differences between the Mean degrees of experimental group in Pre-test and Post-test for optimism.

2. There are no significant differences between the Mean degrees of experimental group in Post -test and Follow up test for optimism.

3. There are no significant differences between the Mean degrees of experimental group in Pre-test and Post-test for Positive Thinking Skills and the total Degree.

4. There are no significant differences between the Mean degrees of experimental group in Post -test and Follow up test for Positive Thinking Skills and the total Degree.

5. There is no statistically significant relationship between the 
future anxiety and all of optimism and positive thinking skills for students in the experimental group after applying of the Development Strategy.

The study provides some recommendations:

1. Reapply development strategy on other samples from different educational levels of the pre-university education.

2. application of strategy on equality in the different educational levels to see the impact that can have on male and female, and the construction of other strategies that help in the construction of optimism and positive thinking and the face of concern for future students parameters.

3. Teach students how to think positive and make it unusual behavior in their lives, in order to meet future challenges and problems.

Key words: development strategy - optimism - positive thinking-future anxiety- Home Economics

\section{Introduction:}

The Undergraduate of reticular stages in the life of the individual, and learners Characterized by mature intellectual who constantly needs to cognitive modern educational activities and contemporary methods of stimulating content to think positive appropriate educational needs renewable for those reactive nature with its age and open to the future of life, and in order to student pass this stage successfully, he must effort, perseverance and bearing the burdens, all of which requires a degree of life satisfaction erosion able to cross this stage safely (Shaqoura,2012: 30). As you can see (Meyer et al., 2007: 35) that they need for individuals optimists who have confidence in their future self, carrying in all directions optimism optimistic outlook positive. We have met the concept of optimism and pessimism large turnout among researchers at the present time what revealed by many studies the impact that can be practiced by optimism feature high pessimism on the lives of individuals and their performance and the rate of their production so it was necessary to work to remove the obstacles and problems that lead learners to a sense of pessimism and loss optimism that prevents him from achieving academic success. 
And refers (Hsiao \& et.al, 2012: 46) goals of modern education thinking patterns develop when learners including positive thinking, which makes the learner identifies ways connected to the success of the predicted good and satisfactory results. And positive mind is happiness, joy, health and a successful outcome in the study and work is expected as encourages the learner to approaching the challenges of life with a positive outlook. This does not necessarily mean that avoids or ignores the bad things. Instead, it involves making the most of cases is likely to be bad, and try to figure out the best in others and offered himself and his abilities in a positive light. And this can be achieved by tracking strategies and development programs to help build optimism came the need for research and exploration on the development strategy contribution through experimentation in achieving high levels of optimism among educated people for the development of optimism and positive thinking as well as to reduce future anxiety.

\section{Research sense of the problem:}

The world is witnessing today a shift unprecedented field of thinking generally positive thinking, especially in the future, particularly, mentions (Seligman, 2009: 13) The human thinker positive nature, and if it has the positive environment we find him acting positively, but if the environment in which the negative grows, it will affect his thinking on the way, as the positive thinking represents the activities and methods used by the individual to address the problems by using the convictions of the mentality of its construction, and to strengthen confidence in the success of the individual through the formation of systems and formats nature optimistic logical mindset. As the optimism and hope pushes the individual to focus on the positive aspects of the positions of pressing it.

\section{The justifications for the research problem in the following:}

- Through the use of Seligman scale to get to know the level of optimism and pessimism among the students of the 
second year specialization "Home Economics," The result was increased by $54.54 \%$ who have a look pessimistic of things and low optimism of the students sample was used to determine which 30 students of the total number (58) They are students of the second Division allocates "the economy of my house."

- In view of students to the future, through societal problems, which are reflected and cast a shadow on personal qualities, and form pressure reflected psychologically, behaviorally, socially them, as well as the scientific ideas to cope with future problems that require new, innovative and effective solutions.

- That man is inherently a positive thinker if it has the positive environment acting positively but if the environment in which they grow a negative influence on his way of thinking, Thinking positively handsome mind to think positively and thus make him successful in doing deeds and skills.

- Due to our lack of this type of studies that develop strategies and development programs that are interested in preparing students / Home Economics parameters for the construction of optimism and positive thinking, reducing concern the future to have, so suggested the researcher development strategy based on a set of strategies and cognitive behavioral when teaching students with a range of styles catalyzed to think positive.

\section{The research problem determined in the following:}

What's the effectiveness of the development strategy in the construction of optimism and positive thinking and the future of their relationship to reduce anxiety among students of Home Economics at the Faculty of Specific Education, Alexandria University?

\section{Ranging questions, including the following:}

1. What are the proposed development strategy to build optimism and positive thinking among students of Home 
Economics at the Faculty of Specific Education, Alexandria University?

2. What is the effectiveness of the proposed development strategy on build optimism

3. The students of Home Economics at the Faculty of Specific Education, Alexandria University?

4. What is the effectiveness of the proposed development strategy is based on positive thinking among students of Home Economics at the Faculty of Specific Education, Alexandria University?

5. Is there a relationship between optimism and positive thinking on the future concern for the students of Home Economics at the Faculty of Specific Education, Alexandria University?

\section{Research importance:}

1. This research is gaining importance from the importance of the variables that covered seeks to build two of optimism and positive thinking and the future of their relationship is concerned, where this study is to keep pace with modern educational trends.

2. Seeking to identify the most important skills might be useful to think positive duty development in order to help the students of Home Economics teachers to reduce future anxiety.

3. Within the limits of science researcher is the first study to provide a development strategy in the field of building optimism and positive thinking and reduce future anxiety among students of Home Economics teachers.

4. Draw the attention of those in charge of the planning and implementation of teacher preparation for the importance of building optimism and positive thinking programs for students.

5. May be useful to the development strategy in the stomach of this research curriculum experts and educators and education in various disciplines and adopting it as a 
model for the preparation and planning of other programs.

6. Generate interest towards addressing future concerns and to identify the causes and how to lower it to the students of Home Economics teachers.

This research is an attempt to enrich the learning environment in general and the environment Home Economics learning in particular using a development strategy proposed that may contribute to achieving some of the goals of teaching "education and the problems of society," the decision of the female students of home economics teachers in access to innovative solutions tendency optimistic positive.

\section{Research objectives:}

The research aims to:

1. The proposed development strategy is designed to build optimism and positive thinking for the students of the Second Division "Industry Home Economics", and in the future to reduce anxiety in women.

2. Identification of the foundations that are based on its development strategy in the construction of optimism and positive thinking and the future of their relationship concerned for the students of the Second Division "Industry Home Economics".

3. Measuring the effectiveness of the development strategy in the construction of optimism and positive thinking and the future of their relationship concerned for the students of the Second Division "Industry Home Economics".

4. Disclosure of the relationship between optimism and positive thinking concern the future for the students of the Second Division "Industry of Home Economics.

\section{Research methodology and tools:}

Approach was used and wound up in the preparation of the theoretical framework and study tools, and in the analysis and interpretation of results, as well as quasi-experimental approach 
because it is the most appropriate for the nature of the study in applied experience and the use of tools applied the following:

1. Optimism and pessimism for Seligman Scale (translation by Barakat, 1998).

2. Scale Positive Thinking Skills (prepared by the researcher).

3. The scale of concern for the future (prepared by the researcher).

4. Proposed development strategy.

\section{Research limits and Sample:}

Limited study on a sample of students in the second period "degree in Economics Home" and they were (30) student low level of optimism, one group, limited study on the teaching of one of the decisions of the program of Home Economics, which is "education and the problems of the community" for the academic year 2015-2016, and the use of the proposed development strategy the study sample.

\section{Research Terms: Known procedurally}

Development strategy: It is a strategy which bringing together a range of strategies (cognitive and behavioral), and a range of styles actors in promoting positive thinking, which is a set of procedures and methods and activities that are used in the construction of optimism and positive thinking for the students of the Second Division of Home Economics Division and reduce the anxiety the future to them.

Optimism: Is a set grade obtained by the student in the optimism of the adoptee researcher scale.

Positive thinking: That the college obtained by the students after the answer to paragraphs positive thinking class scale.

The future anxiety: Adopt a researcher definition (Hntol 2012: 12) on that feeling emotionally disturbed is uncomfortable and thinking negative and distress and discomfort and demonstration lack of social interaction and loss of feeling both 
self-esteem and security, psychological and fear of the future.And defined procedural: It's the sense of the future intimidated by students home Economics to face future problems and the inability to confront and Solution it. And measured by the degree you get the students to answer after future anxiety scale.

\section{"The Theoretical Background to the Research Variables"}

\section{First topic: Optimism}

As seen( tiger) that the hope and optimism that makes the individual possible conditions, The capabilities mentality of the individual is what allows him to see some things in his life, he sends the movement and activity( Peterson \& Seligman, 2004: 527). And then can overcome the difficulties and dealing with stressful situations effectively, Also it confirms (Qasim ,2011: 70) that an individual who have a high degree of optimism is working to produce a large number of solutions to overcome the problems that are likely to stand in front of him to achieve his goals. In terms of the results of optimism building immune system strong increases ability to cope with life stress and adaptation, and optimism is variable important to predict the adaptation and the amount of positive feeling of happiness and satisfaction. To affect the direct attributes optimism and pessimism towards.If was those circumstances and data until the last positive accomplishments no doubt will be the learner look optimism toward the future (Chrome ,2012: 103-104), and there are several theories explain the optimism and pessimism of them (cognitive theory), which showed that human nature holistic system is given the self as an organization a knowledge regarding the history and identity of the individual is subject to direct strategies set (bin Mohammed,2015), and psychoanalytic theory which held that optimism is the general rule for life, and that pessimism is not located in an individual's life unless formed has a psychological complex (Awad, 2012: 53-93). Therefore it requires those in charge of the educational process that is educated about the negative thinking and stimulates positive thinking. 


\section{Second: Positive thinking}

It focused on many of the studies and researches in the recent period the themes of positive psychology and focus on the positive aspects of the character rather than focusing on the negative aspects and unrest. It is the concepts of positive psychology of positive thinking that emerged from several different concepts, including (certain amount submitted by constructivist theory Constructivism Theory thinking. It explains (Fredrickson2001; 218) that consists in the lives of individuals as a result of the positive emotional experiences such as joy, interest, satisfaction, love, and such moments in which the individual does not suffer from the negative emotions such as alkalis sadness, anger and despair. while negative thinking Demolishes and destroys and helps anxiety, and getting rid of doubt and hesitation will increase the time of positive thinking, which helps the ability to concentrate, because it removes factors distractions, and so help us to move forward. As is defined as having an individual for a number of positive optimistic expectations about the future and belief in his ability to succeed, also it represents a sign of success in the ability to tackle the problems by using the convictions of mental construction, and using self-leadership strategies to think, and to strengthen the individual's confidence in success through the formation of systems and consistency with logical mentality the character of my optimism (Suleiman, 2006: 4-107). He learned more think positively and to express ideas and transfer the ability to reach the goals in life and felt successful and think about alternatives useful to talk with oneself positively (Suresh, 2013: 63). The benefits of positive thinking: according to (Taylor, 1983: 116), including:

- A person can adapt better to reality.

- Is associated with high levels of self-esteem

- Increases the vitality of the person and mental health

- Leads to lower levels of depression.

- It provides a sense of control in some cases and reduces the incidence of depression. 


\section{The importance of positive thinking:}

It has pointed out (De Bono 2001: 32) that man can decide his way of thinking, if you choose to think positively can remove a lot of the feelings of unwanted and that may sidetrack for best achievement for yourself, Where the greater flexibility in human whenever it became easy for him to overcome the thinking moments of failure and treat it as the experiences and attitudes learned and mastered.

\section{Positive Thinking Skills:}

Of positive thinking, which noted her skills (Sahada, 2011: 48), which has to be the need to develop in the learners are (problem solving; comparison; planning; ask questions; prioritization Prioritizing; Description; interpretation; Classification; provide alternatives; flexibility; judging things according to precise criteria; reasoning .From the show's former skills of positive thinking that it is necessary to use an effective educational methods in teaching and learning processes to motivate learners to think positive.

\section{Person attributes a positive thinking: that it is:}

Both the (Fredrickson \& Branigan, 2005: 313); (Abdel Gawad, 2014: 80-81) that an individual's positive to be:

1. With positive feelings and mood positive and the positive feelings be interconnected benefits, including changing emergency and methods of thinking.

2. Flexible in their behavior and dealing with life situations.

3. Increases the individual's positive level of intuition and creativity.

4. Broadens the scope of individual perception, attention, and hard work.

5. Happy person is characterized by bright vision, and the ability to manage crises positive and optimistic feelings.

6. A multiplicity of positive coping strategies and personal settings for the feelings and negative thoughts when faced with various tensions and pressures of life. 
So it must adopt teaching centered learner strategies and develop their abilities and encourage active participation, along with activities encourage positive thinking and explore alternative visions and apply the methodologies learned trial of (the United Nations, the Organization of 0.2012: 24-26). So he has a high degree of strength of cognitive control over the activities and actions cognitive practice so that they can realize the future. Such a study (Al-Alfy, 2016), which confirmed the effectiveness of a proposed program to the development of positive thinking among the study sample of adolescents and relieve anxiety they have. She also noted a study (Al-Husseini ,2016) the absence of statistical differences between the average male and female students of university degrees in the positive thinking and negative for the total score and the dimensional scale, except after me talk positive at the level of the same, and the presence of relational positive and statistically significant between positive thinking and academic motivation and direction relationship towards the teaching profession at the faculties of education students. A study Showed (Khouly, 2012) the impact of positive thinking on academic ambition among female students arrears of study for the experimental group.

\section{Third: Future anxiety}

The future anxiety also agreed each of the (Presbyterian, 2009: 74); (Al-Husseini, 2011: 25) is feeling insecurity, and predicted a disaster in response to a possible non-existent, but it is expected in the future. Where the phenomenon of future concern became clear in full of changes society in all areas, resulting in a feeling of unease, and the inability to cope with the problems and challenges pressing in life, where he confirmed the study (Almhakbh, 2015) on the relationship between quality of life and the concern of the future, where I found a correlation a negative and statistically significant between quality of life and the concern of the future, and that it can predict the future of the concern over the quality of life. A study (confirmed (Kapka et al., 2013) and the presence of correlation between optimism and 
anxiety and health-related quality of life. The study Badawi (2013), which confirmed the presence of a positive correlation between the anxiety and stress future.

\section{The most important reasons that lead to the future anxiety:}

As clarified by many researches and studies for each of the (Jabr, 2012:45); (Husseiny, 2011: 42), as follows:

- One of the most important life pressures that cause concern future factors.

- Feeling nervous and pessimistic forecast bad and narrows the future.

- As a result of the tension arising from the decision-making responsibility, automatic trans, ideas, and erroneous interpretations of events as a sort of mental conflict.

- An inability to adapt to the problems experienced by the individual.

- Conversations of the individual self and to his ideas for defeated with outlines Pressures life resulting from a change in lifestyles, which in turn reflected on their own behavior and patterns of thinking.

- Inability to compatibility with the problems experienced by the individual.

- lack of effectiveness of the individual in dealing with future events

- Inability to confront problems and not to feeling tranquility and security.

- Irrational thinking which attention's man, and exaggeration of looking at life issues, which creates a feeling of helplessness and vulnerability.

\section{The implications on future anxiety:}

There are negatives to worry about the future is the high degree of anxiety about the extent that impedes the proper individual and social performance and mental functions, effectively feels tense and narrow . (Al Ghamdi, 2012: 130)Says 
that the individual feels disturbed and narrow and faulty psychiatric disorder caused by unpleasant experiences, and the feeling of security and peace of mind of those who paid to self and the deficit is clear and circulation failure destroyed.

Fourth: The importance of preparing students / Home Economics parameters for the study of "education and the problems of society," the decision tendency optimistic and positive impacts on teaching and learning processes and the anxiety for the future have:

Based on the importance of optimism and positive thinking and make it a way of life and this requires awareness of learner's university stage variables 21st century development, and develop their abilities to solve problems positively. So you may chose researcher applied this strategy to a decision, "Education and the problems of the community," the Second Division allocates domestic economy which is one of the decisions of the program of Home Economics at the Faculty of Specific Education, Alexandria University, and given the close link between education decision of social problems and the nature of specialization, where he knew that the domestic economy is science and closely related to the problems of society, as recommended by the study of all (Abdel Azim, 2008), and the study of El-Madhon in 2004), the need to link the student / teacher, community and environmental problems setting.

This enables us to draw the negative and positive effects of anxiety on the future students of Home Economics, it is the positive effects that pushes the individual towards the integrated growth in his character, and look at the future with optimism, the negative effects may not represented in the student's ability to:

- Confront and resolve problems.

- Estimate the value of time and time management in a good way.

- Academic achievement and good compatibility. 
- Adapt to the economic conditions and the ability to meet future needs.

- Setting goals and aspirations and enjoyment to a level of self-motivation to accomplish.

- Social compatibility with her family and those around them.

This is the preparation of a teacher of Home Economics stage is the pillar of basic undertaking the process of teaching and learning in an effective and positive, so you must provide the student / teacher implications for the characteristic optimism and skills of positive thinking their behavior future, and how to cope with these problems to acquisition set of life skills that qualifies them to avoid them high-powered even to contribute to building optimism and stimulate student / teacher to think positively about various societal problems look optimistic positive, as confirmed (Hntol, 2012:16) young people live in a state of anxiety on his life and his future considered pessimistic for the future and frustration as a result of the inability to achieve its goals And so that we can develop positive thinking among students / Home Economics parameters they must take into account the following:

1. Treat weaknesses when students and evaluation them.

2. Diversification in teaching methods that you use.

3. Preservation of love and respect between students and teacher.

4. Using several methods of stimulating positive thinking.

5. Encourage them to produce creative ideas and the development of academic self-motivation in them.

\section{"Method and procedures"}

\section{The proposed strategy:}

Development strategy is an effective strategy in building optimism and positive thinking for the students of the Second Division of Home Economics Division and reduce future their anxiety, which is derived from: 


\section{First group of teaching strategies such as:}

1. Self - Talk Strategy: where it enables learners to increase the monitoring and evaluation of internal ideas to the expectations of the individual to succeed in solving the problems, and increase the individual's ability to selfmanagement to think of the positive points, becoming the most control over involuntary way of thinking and trends operations (Khatib, 2003: 333).

2. Cognitive Restructuring (CR) : These include the reorganization of cognitive area, and reorganizing ideas, relevant links between events and various environmental stimuli, which would develop the self-control strategies of the learner (Marlene. G. Cooper, 2009: 153-154).

3. Modeling Cognitive: which is to instill in new behaviors, make and model of the methodology of the distinguished persons who have achieved excellence, which will enable them to repeat such a concession (Hiten S., 2007: 30).

4. Role-playing: It is based on the reincarnation of the individual's personality relate to his problem and then exchange roles so that the individual himself puts the other place, which leads to emotional catharsis, which trains the learner to the performance aspects of social behavior can be acquired and mastered the skill.

5. Problem Solving: which steps to resolve the problem, such as a group (identified and set goals and generate alternatives that can be used and evaluate the alternatives and associated results and finally choose the right solution and the design plan and practice (Neven 2009: 21).

6. Thought Self Leadership Strategy: a control of the thinking control strategies, and are intended to lead the individual's mental activities and inner thoughts and convictions is determined by which time and speed and as a result of the process of thinking (Enzi 2007: 41). 


\section{Second:}

The group of styles actors in promoting the proper mindset (positive), such as:

- Encouragement and motivation.

- Fruitful mutual dialogue.

- Positive reinforcement.

- Induction to follow distinct models.

- Advice and guidance.

- Relax.

First: The objective of the strategy:

The researcher preparing parameter guide for guidance during teaching sessions for students in accordance with the development strategy, building optimism and positive thinking for the students of the Second Division of Home Economics Division and reduce future anxiety to them.

\section{Second: the strategy described:}

The design of the development strategy in the light seen by the researcher of theoretical frameworks in the literature and specialized studies and scientific journals, which focused on studying the optimism and positive thinking.

Table (1) A description of the content and sessions development strategy

\begin{tabular}{|c|l|c|c|c|}
\hline session & \multicolumn{1}{|c|}{ Session subject } & $\begin{array}{c}\text { number } \\
\text { of } \\
\text { sessions }\end{array}$ & $\begin{array}{c}\text { number } \\
\text { of } \\
\text { hours }\end{array}$ & $\begin{array}{c}\text { number } \\
\text { of } \\
\text { weeks }\end{array}$ \\
\hline First & $\begin{array}{l}\text { Acquaintance and pretest of } \\
\text { research tools. }\end{array}$ & 1 & 2 & 1 \\
\hline Second & $\begin{array}{l}\text { Education (concept - goals - } \\
\text { importance) }\end{array}$ & 1 & 2 & 1 \\
\hline Third & Social Problems & 1 & 2 & 1 \\
\hline Fourth & The problem of "poverty" & 1 & 2 & 1 \\
\hline Fifth & The problem of street children & 1 & 2 & 1 \\
\hline Sixth & The problem of dropouts & 1 & 2 & 1 \\
\hline Seventh & $\begin{array}{l}\text { The problem of over } \\
\text { population }\end{array}$ & 1 & 2 & 1 \\
\hline Eighth & $\begin{array}{l}\text { The problem of smoking and } \\
\text { drug addiction }\end{array}$ & 1 & 2 & 1 \\
\hline ninth & Posttest research tools & 1 & 2 & 1 \\
\hline \multicolumn{2}{|c|}{ total } & 9 & 18 & 9 \\
\hline
\end{tabular}


Table (2) the strategy consisted of a number of the following sessions

\begin{tabular}{|c|c|c|}
\hline Session & Session subject & The goal of the session \\
\hline 1 & $\begin{array}{l}\text { Acquaintance and } \\
\text { pretest of research } \\
\text { tools. }\end{array}$ & $\begin{array}{l}\text { Acquaintance between the researcher } \\
\text { and the students and show the nature of } \\
\text { the hearings and the goals and agree on } \\
\text { appointments and attendance and } \\
\text { attendance and identify the different } \\
\text { emotions and promote teamwork }\end{array}$ \\
\hline 2 & $\begin{array}{l}\text { Education (concept - } \\
\text { goals - importance) }\end{array}$ & $\begin{array}{l}\text { Identify the process of education, its } \\
\text { concept and its objectives and its } \\
\text { importance and the role it plays in } \\
\text { people's lives. And provide the rationale } \\
\text { behind the development strategy with } \\
\text { the promotion and encouragement }\end{array}$ \\
\hline 3 & Social Problems & $\begin{array}{l}\text { Through discussions devise researcher } \\
\text { whom social problems from their } \\
\text { perspective and what is causing concern } \\
\text { to have pressure. The researcher is } \\
\text { trying to cognitive restructuring and } \\
\text { provide ideas Constructivism }\end{array}$ \\
\hline 4 & $\begin{array}{l}\text { The problem of } \\
\text { "poverty" }\end{array}$ & $\begin{array}{l}\text { To identify the causes of the problem of } \\
\text { poverty and access to them how to solve } \\
\text { reconstruction Cognitive have to - and to } \\
\text { promote positive relations }\end{array}$ \\
\hline 5 & $\begin{array}{l}\text { The problem of } \\
\text { street children }\end{array}$ & $\begin{array}{l}\text { To identify the reasons for the spread of } \\
\text { the problem of street children and access } \\
\text { to them how to solve reconstruction have } \\
\text { cognitive and promote positive relations }\end{array}$ \\
\hline 6 & $\begin{array}{l}\text { The problem of } \\
\text { dropouts }\end{array}$ & $\begin{array}{l}\text { To identify the reasons for the spread of } \\
\text { dropping out of education and access to } \\
\text { them how to solve reconstruction } \\
\text { Cognitive - and to promote positive } \\
\text { relation }\end{array}$ \\
\hline 7 & $\begin{array}{l}\text { The problem of over } \\
\text { population }\end{array}$ & $\begin{array}{l}\text { To identify the causes of population } \\
\text { growth and access to them how to solve } \\
\text { reconstruction Cognitive - and to } \\
\text { promote positive relations }\end{array}$ \\
\hline 8 & $\begin{array}{l}\text { The problem of } \\
\text { smoking and drug } \\
\text { addiction }\end{array}$ & $\begin{array}{l}\text { To identify the reasons for the } \\
\text { prevalence of smoking and drug } \\
\text { addiction, especially at a young age and } \\
\text { access to them how to solve } \\
\text { reconstruction Cognitive - and to } \\
\text { promote positive relations }\end{array}$ \\
\hline 9 & $\begin{array}{c}\text { Posttest research } \\
\text { tools }\end{array}$ & $\begin{array}{l}\text { Emphasis on the emotional health and } \\
\text { the importance of positive engagement } \\
\text { and look to the future bright - then the } \\
\text { posttest application of research tools to } \\
\text { demonstrate the effectiveness of the } \\
\text { development strategy }\end{array}$ \\
\hline
\end{tabular}




\section{Validity development strategy:}

The development strategy introduced in the initial image on the number (10) of the curriculum professors and teaching methods and educational psychology and mental health at Egyptian universities, accompanied by a preliminary introduction included an explanation of the research, the goal of it, and the definition of procedural terminology, that the total percentage of the agreement before the jury on the validity of the development strategy of (89\%), a high proportion of agreement; which refers to the development strategy for the application of the validity and reliability results that will result in her research.

Table (3) agreement gentlemen arbitrators ratios on the development strategy $(n=10)$

\begin{tabular}{|c|c|c|c|c|}
\hline $\mathbf{N}$ & Item & \begin{tabular}{|l} 
Number \\
Times \\
the \\
agreement
\end{tabular} & \begin{tabular}{|l} 
Number \\
Times \\
the \\
difference
\end{tabular} & $\begin{array}{c}\text { Rate } \\
\text { the } \\
\text { agreement }\end{array}$ \\
\hline 1 & $\begin{array}{l}\text { The clarity of the developmental } \\
\text { strategy objectives. }\end{array}$ & 10 & 0 & $100 \%$ \\
\hline 2 & $\begin{array}{l}\begin{array}{l}\text { Interdependence } \\
\text { development strategy goals and } \\
\text { content. }\end{array} \\
\end{array}$ & 9 & 1 & $90 \%$ \\
\hline 3 & $\begin{array}{l}\text { Logical sequence of the development } \\
\text { strategy of the content }\end{array}$ & 8 & 2 & $80 \%$ \\
\hline 4 & $\begin{array}{l}\text { Interdependence between } \\
\text { development strategy sessions }\end{array}$ & 9 & 1 & $90 \%$ \\
\hline 5 & $\begin{array}{l}\text { Adequacy of the duration of the } \\
\text { planned development strategy. }\end{array}$ & 9 & 1 & $90 \%$ \\
\hline 6 & $\begin{array}{l}\text { Effective teaching strategies and } \\
\text { how they relate to the development } \\
\text { of strategic objectives. }\end{array}$ & 8 & 2 & $80 \%$ \\
\hline 7 & $\begin{array}{l}\text { Effective educational methods used } \\
\text { and how they relate to the } \\
\text { development of strategic objectives. }\end{array}$ & 9 & 1 & $90 \%$ \\
\hline 8 & $\begin{array}{l}\text { Effectiveness of different activities } \\
\text { and how they relate to the } \\
\text { development of strategic objectives. }\end{array}$ & 8 & 2 & $80 \%$ \\
\hline 9 & $\begin{array}{l}\text { Integration between } \\
\text { activities. }\end{array}$ & 10 & 0 & $100 \%$ \\
\hline 10 & $\begin{array}{l}\text { Sufficiency and appropriateness of } \\
\text { evaluation methods used in the } \\
\text { development strategy. }\end{array}$ & 9 & 1 & $90 \%$ \\
\hline & & \multicolumn{3}{|c|}{$89 \%$} \\
\hline
\end{tabular}




\section{Second: preparation of the Search Tools:}

(Exploratory sample: aimed at making sure the psychometric characteristics of the research tools (honesty consistency), and the following table describes the exploratory sample)(Basic sample: Experimental design).

\begin{tabular}{|l|l|l|l|}
\hline the group & The pretest & $\begin{array}{l}\text { Independent } \\
\text { variable }\end{array}$ & The post test \\
\hline Experimental & $\begin{array}{l}\text { Optimism and } \\
\text { pessimism scale }\end{array}$ & $\begin{array}{l}\text { Development } \\
\text { strategy }\end{array}$ & $\begin{array}{l}\text { Optimism and } \\
\text { pessimism scale }\end{array}$ \\
\hline Control & $\begin{array}{l}\text { Testing positive } \\
\text { thinking skills }\end{array}$ & Traditional & $\begin{array}{l}\text { Testing positive } \\
\text { thinking skills }\end{array}$ \\
$\begin{array}{l}\text { Future anxiety } \\
\text { scale }\end{array}$ \\
\hline
\end{tabular}

\section{(1) Psychometric Properties for Optimism Scale Seligman:}

Scale Description: This scale aims at measure the degree of Optimism and pessimism for students of Home Economics at the Faculty of Specific Education, Alexandria University. And this scale is prepared by Seligman which consists of (48) followed by a paragraph each ferries Screened asked to choose one of them, where one of them reflect the individual's response to optimism, while the other reflects the pessimistic response. As it gives the student one grade for each answer is in the right direction, whether toward optimism towards pessimism feature or trait. The researcher has to rebuild and drafting paragraphs scale to suit the local environment. The researcher has identified scores of (0-24) as an indicator of pessimism feature, and grades (2548 ) as a sign of optimism feature.

B. Believe Seligman scale: To calculate the psychometric properties of the scale Seligman study was based on honesty expense to study both (Barakat, 1998), where the extraction of honesty necessary between the scale and measure Eysenk personality and was their correlation to (0.73); and study (Ainu Abdullah 0.2016), where the use of sincerity peripheral comparison to a sample (31), a student of the third year, "Education technology Industry in Algeria" the result was the ability of the test using the "T" 2.76 which is significant at the 
0.05 level, and this Seligman scale is considered to be the psychology of optimism and pessimism honest to put the measure.

C. Factorial Validity: Factorial Validity Depends on Method of factorial analysis, a method of test ingreveal the extent of saturation of the factors that make up the. (Faraj, S, 1991: P 17), The Above Table Shows that there is just one factor explains (63.541\%) of the variance in performance on Optimism scale and all the Questions of scale was saturated by substantially; so it can be called a factor of Optimism, and it has a standard high degree of Validity, which refers to the possibility of use in the current research, and to trust the results.

D. Scale Reliability: The researcher calculated the Reliability of Optimism Scale by a Cronbach's alpha the reliability coefficient for the scale was (0.827); and by using test re-test method the reliability coefficient for the scale was $\left(0.869^{* *}\right)$ this means that the Scale has a high degree of Reliability, suggesting the possibility of use in the current research, and to trust the results.

\section{(2) Psychometric Properties for Positive Thinking Scal}

(A). Scale Description: The scale aims at measure the degree of Positive thinking Skills for students of Home Economics at the Faculty of Specific Education, Alexandria University. To build this test, I came across researcher on several studies of Arab and foreign research on the subject of positive thinking like skills (Alfy,2016), (Al Enzi, 2007), (Saida,2005), This scale measures a five skills which (Mental Inference Skill Problem Solving Skill - Provide alternatives Skill - Judging on things Skill - Classification Skill) and scale contents of (36)Items.

(B). Scale Validity: The researcher calculates Scale Validity by using Lawshe Content Validity Ratio (CVR) where the scale was presented to number (10) of the curriculum professors and teaching methods and Home Economics at Egyptian universities, 
the average of Lawshe Content Validity Ratio for the scale was $(0.823)$ and this is acceptable Validity percentage.

(c) Factorial Validity: Factorial Validity Depends on Method of factorial analysis, a method of testing reveal the extent of saturation of the factors that make up the. (Faraj, S, 1991, P 17), the below Table indicates The Results of factorial analysis to the Positive thinking Scale. The Above Table Shows that there is just one factor explains (65.089\%) of the variance in performance on Positive thinking scale and all the Questions of scale was saturated by substantially; so it can be called a factor of Positive thinking, and it has a standard high degree of Validity, which refers to the possibility of use in the current research, and to trust the results.

(D) Scale Reliability: The researcher calculated the Reliability of Positive thinking Scale by a Cronbach's alpha the reliability coefficient for the scale was (0.848); and by using test re-test method the reliability coefficient for the scale was $\left(0.890^{* *}\right)$ this means that the Scale has a high degree of Reliability, suggesting the possibility of use in the current research, and to trust the results.

(E) Scale Answer time: The researcher depended on the answer time for Upper quartile and for Lower quartile to calculate the Scale Answer time and below table shows the Answer time of Positive Thinking Scale.

Table (4) the Answer time of Positive Thinking Scale $(N=30)$

\begin{tabular}{|c|c|c|c|}
\hline Variable & $\begin{array}{c}\text { Average } \\
\text { Duration for } \\
\text { Upper quartile } \\
(\mathrm{N}=10)\end{array}$ & $\begin{array}{c}\text { Average } \\
\text { Duration for } \\
\text { Lower quartile } \\
(\mathrm{N}=10)\end{array}$ & Answer time \\
\hline $\begin{array}{c}\text { Answer } \\
\text { time }\end{array}$ & $\mathbf{4 0 . 5 3}$ Minutes & $\mathbf{5 9 . 2 6}$ Minutes & $\mathbf{4 9 . 8 9}$ Minutes \\
\hline
\end{tabular}

And the above table shows that the Answer time of Positive Thinking Scale is (50) Minutes.

(F) The test method Correction: After applying it to exploratory group and number (30) Student, the researcher Give 
one degree each item required in the test to be the degree to which each student get sandwiched between (0-50) degrees.

\section{(3) Future anxiety scale:}

(A).Scale Description: This scale aims at measure the degree of Future anxiety for students of Home Economics at the Faculty of Specific Education, Alexandria University. This scale measures a five skills which consists of a paragraph (32) divided into five areas consist of (Social Anxiety- Economic AnxietyOccupational Anxiety- Family Anxiety- Health Anxiety) .

(B) Scale Validity: The researcher calculates Scale Validity by using Lawshe Content Validity Ratio (CVR) where the scale was presented to number (10) of the curriculum professors and teaching methods and Home Economics at Egyptian universities, the average of Lawshe Content Validity Ratio for the scale was (0.784) and this is acceptable Validity percentage.

(C)Factorial Validity: Factorial Validity Depends on Method of factorial analysis, method of testing reveal the extent of saturation of the factors that make up the. (Faraj, S, 1991, P 17), the below Table indicates The Results of factorial analysis to the Future anxiety Scale. The Above Table Shows that there is just one factor explains (59.667\%) of the variance in performance on Future anxiety scale and all the Questions of scale was saturated by substantially; so it can be called a factor of Future anxiety, and it has a standard high degree of Validity, which refers to the possibility of use in the current research, and to trust the results.

(D). Scale Reliability: The researcher calculated the Reliability of Future anxiety Scale by a Cronbach's alpha the reliability coefficient for the scale was (0.811); and by using test re-test method the reliability coefficient for the scale was $\left(0.853^{* *}\right)$ this means that the Scale has a high degree of Reliability, suggesting the possibility of use in the current research, and to trust the results.

(E). Corrected measure of concern to the future: An answer pattern on each vertebra through an alternative of the 
four alternatives to choose, in order to get the total score for the measure concerns the future, have been identified alternatives are as follows (always, often, sometimes, rarely), and was given a score for each alternative of the four alternatives are as follows: paragraphs positive $(3,2,1,0)$, the negative paragraphs: $(0,1,2,3)$. And it became the measure in its final form consists of $(32$ (, paragraph (11 (positive paragraph, and (21 (negative, with the highest degree of the scale (96) was the lowest score is the (zero).

\section{"Results"}

First hypothesis: There are no significant differences between the Mean degrees of experimental group in Pre-test and Post-test for optimism.

Table (5) The results of $t$ _Test for significant differences between the Mean degrees of experimental group in Pre-test and Post-test for optimism $(\mathrm{N}=30)$

\begin{tabular}{|c|c|c|c|c|c|c|c|c|}
\hline & \multicolumn{2}{|c|}{ Pre Test } & \multicolumn{2}{c|}{ Post Test } & \multicolumn{2}{c|}{$\begin{array}{c}\text { Significant } \\
\text { differences }\end{array}$} & \multicolumn{2}{c|}{ Eta-squared, $\eta^{2}$} \\
\cline { 2 - 9 } & Mean & SD & Mean & SD & $\begin{array}{c}\text { t- } \\
\text { Value }\end{array}$ & $\begin{array}{c}\text { Significance } \\
\text { level }\end{array}$ & Value & Significance \\
\hline Optimism & 26.18 & 4.83 & 45.20 & 1.69 & 22.477 & 0.01 & 0.946 & High \\
\hline
\end{tabular}

There are significant differences at the level of significance (0.01) between the Mean degrees of experimental group in Pretest and Post-test for optimism for the Post-test. Which returns to development strategy is to (94.6\%). And The Below figure shows the bar charts for Mean degrees of experimental group in Pre-test and Post-test for optimism.

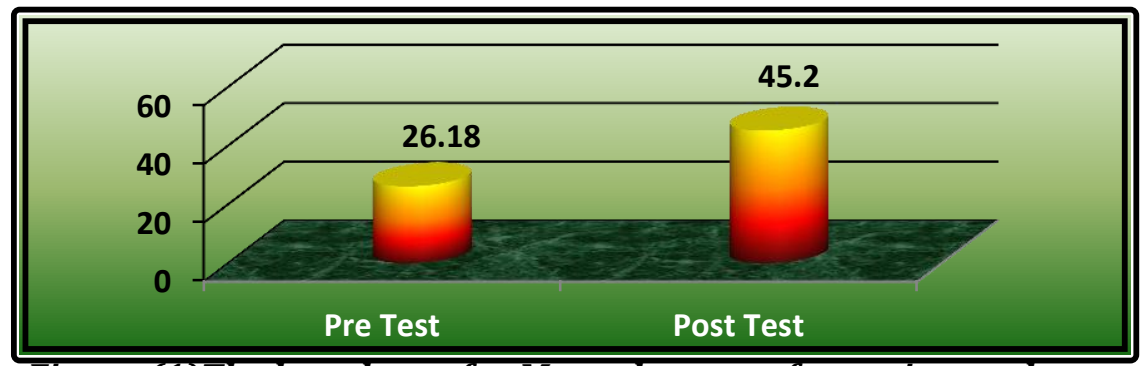

Figure (1)The bar charts for Mean degrees of experimental group in Pre-test and Post-test for optimism 
This result is consistent with the results of several studies and previous research, such as: (Barakat, 1998),( Abdallah,2016).And the researcher attributed this result to the following reasons: The researcher attributed this result to the superiority of the experimental group in the optimism scale to the strategy that provided for the students, And dependence on a number of cognitive and behavioral strategies as well as some motivational tactics for optimism and positive thinking as they stepped up activity and competition for students through encouragement and reinforcement and support positive support.

Second hypothesis: There are no significant differences between the Mean degrees of experimental group in Post test and Follow up test for optimism.

Table (6) the results of $t$-Test for significant differences between the Mean degrees of experimental group in Post-test and Follow up test for optimism $(N=30)$

\begin{tabular}{|c|c|c|c|c|c|c|}
\hline \multirow{2}{*}{} & \multicolumn{2}{|c|}{ Post Test } & \multicolumn{2}{c|}{$\begin{array}{c}\text { Follow up } \\
\text { Test }\end{array}$} & \multicolumn{2}{c|}{ Significant differences } \\
\cline { 2 - 7 } & Mean & SD & Mean & SD & t- Value & $\begin{array}{c}\text { Significance } \\
\text { level }\end{array}$ \\
\hline optimism & 45.20 & 1.69 & 44.33 & 3.56 & 1.298 & Not Significant \\
\hline
\end{tabular}

The previous table shows that there are no significant differences at the level of significance (0.05) between the Mean degrees of experimental group in Post -test and Follow up test for optimism and the total Degree. And The Below figure shows the bar charts for Mean degrees of experimental group in Post test and Follow up test for optimism

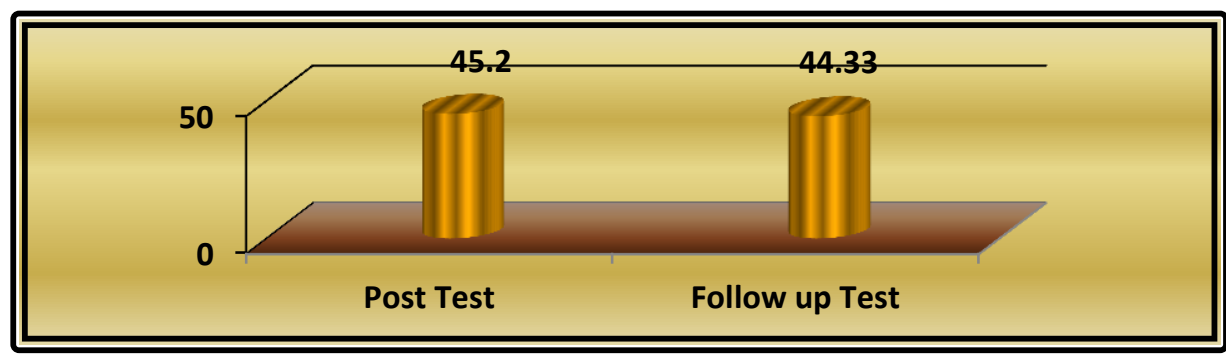

Figure (2) the bar charts for Mean degrees of experimental group in Post -test and Follow up test for optimism 
The researcher attributed this result to the following reasons, The researcher attributed the lack of differences between the two measurements after and observable strategy, And adoption of the strategy on the positive self that develop in students self-confidence and optimism confidence modern and behavior change to the positive and agreed with the study (Amany Ibrahim, 2005) in that it increases the individual's ability to solve problems and the continued survival of the effect was due to the use of imagination strategy in many positions which generate mental image and mindset allows the learner to experience the situation, which did not materialize in reality.

Third hypothesis: There are no significant differences between the Mean degrees of experimental group in Pre-test and Post-test for Positive Thinking Skills and the total Degree.

Table (7) The results of t_Test for significant differences between the Mean degrees of experimental group in Pre-test and Post-test for Positive Thinking Skills and the total Degree $(\mathrm{N}=30)$

\begin{tabular}{|c|c|c|c|c|c|c|c|c|}
\hline & \multicolumn{2}{|c|}{ Pre Test } & \multicolumn{2}{c|}{ Post Test } & \multicolumn{2}{c|}{$\begin{array}{c}\text { Significant } \\
\text { differences }\end{array}$} & \multicolumn{2}{c|}{ Eta-squared, $\eta^{2}$} \\
\cline { 2 - 8 } & Mean & SD & Mean & SD & $\begin{array}{c}\text { t- } \\
\text { Value }\end{array}$ & $\begin{array}{c}\text { Significance } \\
\text { level }\end{array}$ & Value & Significance \\
\hline $\begin{array}{c}\text { Mental } \\
\text { Inference } \\
\text { Skill. }\end{array}$ & 1.43 & 1.04 & 3.60 & 0.97 & 7.857 & 0.01 & 0.680 & High \\
\hline $\begin{array}{c}\text { Problem } \\
\text { Solving Skill. }\end{array}$ & 5.13 & 2.01 & 13.37 & 1.50 & 18.660 & 0.01 & 0.923 & High \\
\hline $\begin{array}{c}\text { Provide } \\
\text { alternatives } \\
\text { Skill. }\end{array}$ & 1.60 & 1.25 & 4.50 & 1.22 & 8.281 & 0.01 & 0.703 & High \\
\hline $\begin{array}{c}\text { Judging on } \\
\text { things Skill. }\end{array}$ & 1.77 & 1.57 & 4.53 & 1.25 & 8.356 & 0.01 & 0.707 & High \\
\hline $\begin{array}{c}\text { Classification } \\
\text { Skill. }\end{array}$ & 1.93 & 1.51 & 5.33 & 1.52 & 9.597 & 0.01 & 0.761 & High \\
\hline $\begin{array}{c}\text { Total } \\
\text { Degree }\end{array}$ & 11.87 & 3.28 & 31.33 & 4.38 & 22.060 & 0.01 & 0.944 & High \\
\hline
\end{tabular}


The previous table shows that there are significant differences at the level of significance $(0.01)$ between the Mean degrees of experimental group in Pre-test and Post-test for Positive Thinking Skills and the total Degree for the Post-test.

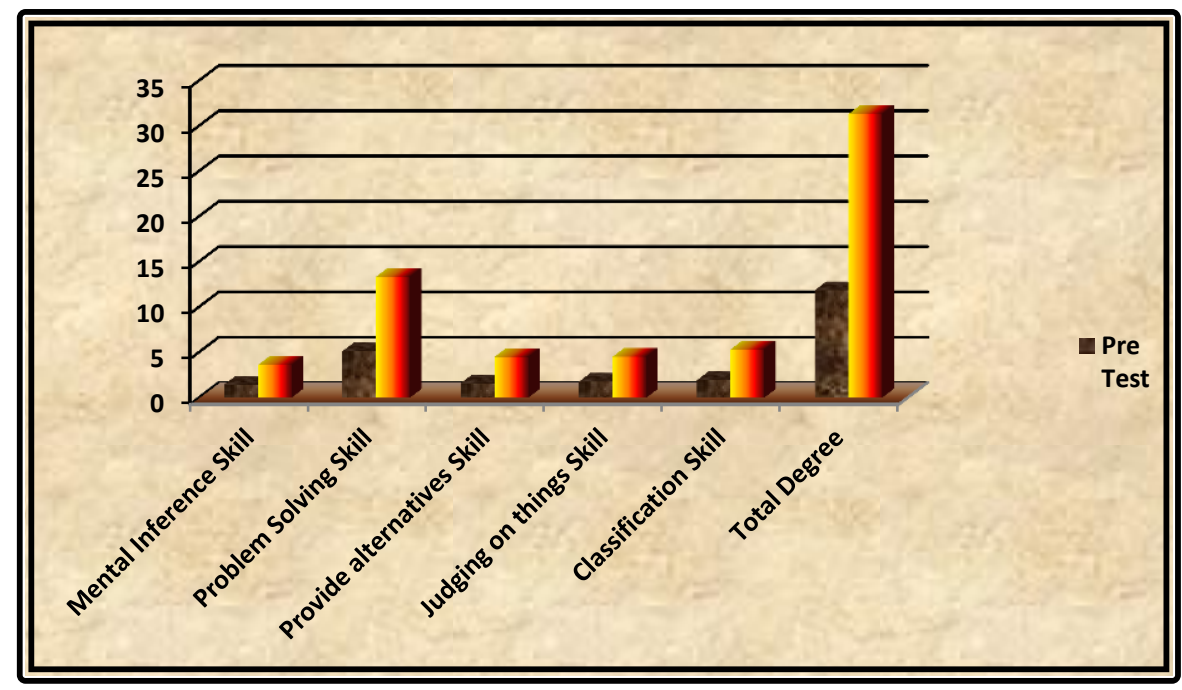

Figure (3) the bar charts for Mean degrees of experimental group in Pre-test and Post-test for Positive Thinking Skills

This result is consistent with the results of several studies and previous research, such as: (Alfy, 2016),( Anzi, 2007).And the researcher attributed this result to the following reasons, researcher positive impact of the strategy due to the use of positive reinforcement to students during the strategic application led to increased cooperation and the determination and the discussion between them to come up with many positive thoughts and evidence help to stimulate ideas pessimism dominates the implant during exposure to the problems which helped to communicate and download Social Responsibility.

Fourth hypothesis: There are no significant differences between the Mean degrees of experimental group in Post test and Follow up test for Positive Thinking Skills and the total Degree. 
Table (8) The results of $t_{-}$Test for significant differences between the Mean degrees of experimental group in Post-test and Follow up test for Positive Thinking Skills and the total Degree $(N=30)$

\begin{tabular}{|c|c|c|c|c|c|c|}
\hline & \multicolumn{2}{|c|}{ Post Test } & \multicolumn{2}{|c|}{$\begin{array}{c}\text { Follow up } \\
\text { Test }\end{array}$} & \multicolumn{2}{c|}{ Significant differences } \\
\cline { 2 - 7 } & Mean & SD & Mean & SD & $\begin{array}{c}\text { t- } \\
\text { Value }\end{array}$ & $\begin{array}{c}\text { Significance } \\
\text { Level }\end{array}$ \\
\hline $\begin{array}{c}\text { Mental } \\
\text { Inference Skill. }\end{array}$ & 3.60 & 0.97 & 3.20 & 1.24 & 1.649 & Not Significant \\
\hline $\begin{array}{c}\text { Problem } \\
\text { Solving Skill. }\end{array}$ & 13.37 & 1.50 & 13.03 & 1.81 & 1.262 & Not Significant \\
\hline $\begin{array}{c}\text { Provide } \\
\text { alternatives } \\
\text { Skill. }\end{array}$ & 4.50 & 1.22 & 4.17 & 1.37 & 1.284 & Not Significant \\
\hline $\begin{array}{c}\text { Judging on } \\
\text { things Skill. }\end{array}$ & 4.53 & 1.25 & 4.37 & 1.27 & .587 & Not Significant \\
\hline $\begin{array}{c}\text { Classification } \\
\text { Skill. }\end{array}$ & 5.33 & 1.52 & 5.10 & 1.73 & .646 & Not Significant \\
\hline $\begin{array}{c}\text { Total Degree } \\
\text { T1.33 }\end{array}$ & 4.38 & 29.87 & 4.66 & 1.724 & Not Significant \\
\hline
\end{tabular}

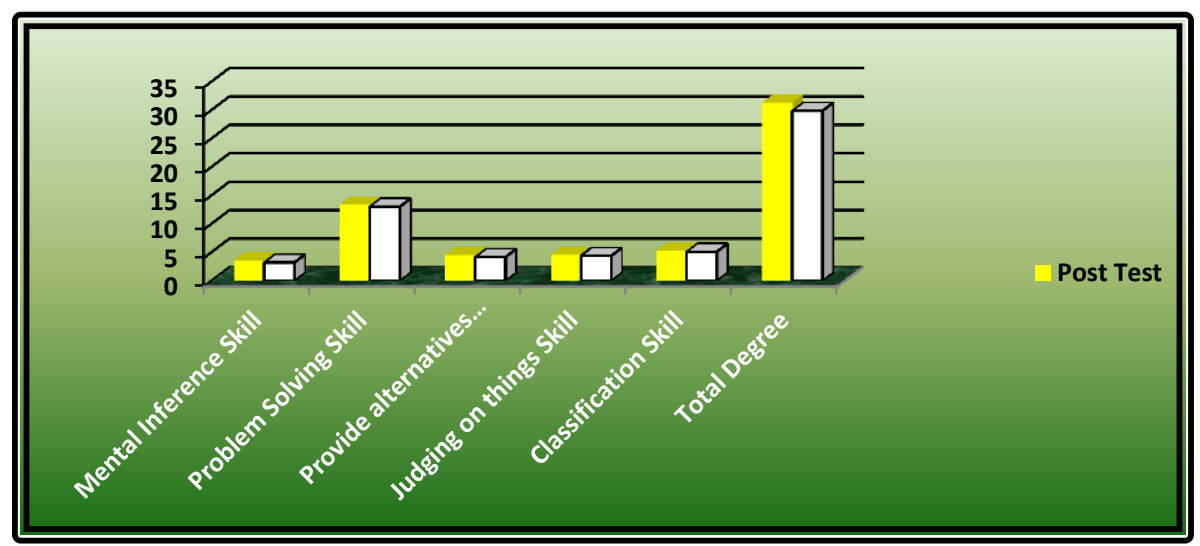

Figure (4) the bar charts for Mean degrees of experimental group in Post -test and Follow up test for Positive Thinking Skills

The researcher attributed this result to the following reasons, Adoption of the strategy role-playing (after continuity), which discussed the role of exercise and cognitive reconstruction, where the expansion of horizons and develop self-confidence and increases the imagination of students and develop to have the intellectual flexibility. 
Five hypothesis : There is no statistically significant relationship between the future anxiety and all of optimism and positive thinking skills for students in the experimental group after applying of the Development strategy.

Table (9) The Correlation Matrix between the future anxiety and all of optimism and positive thinking skills for students in the experimental group after applying of the Development strategy $(N=30)$

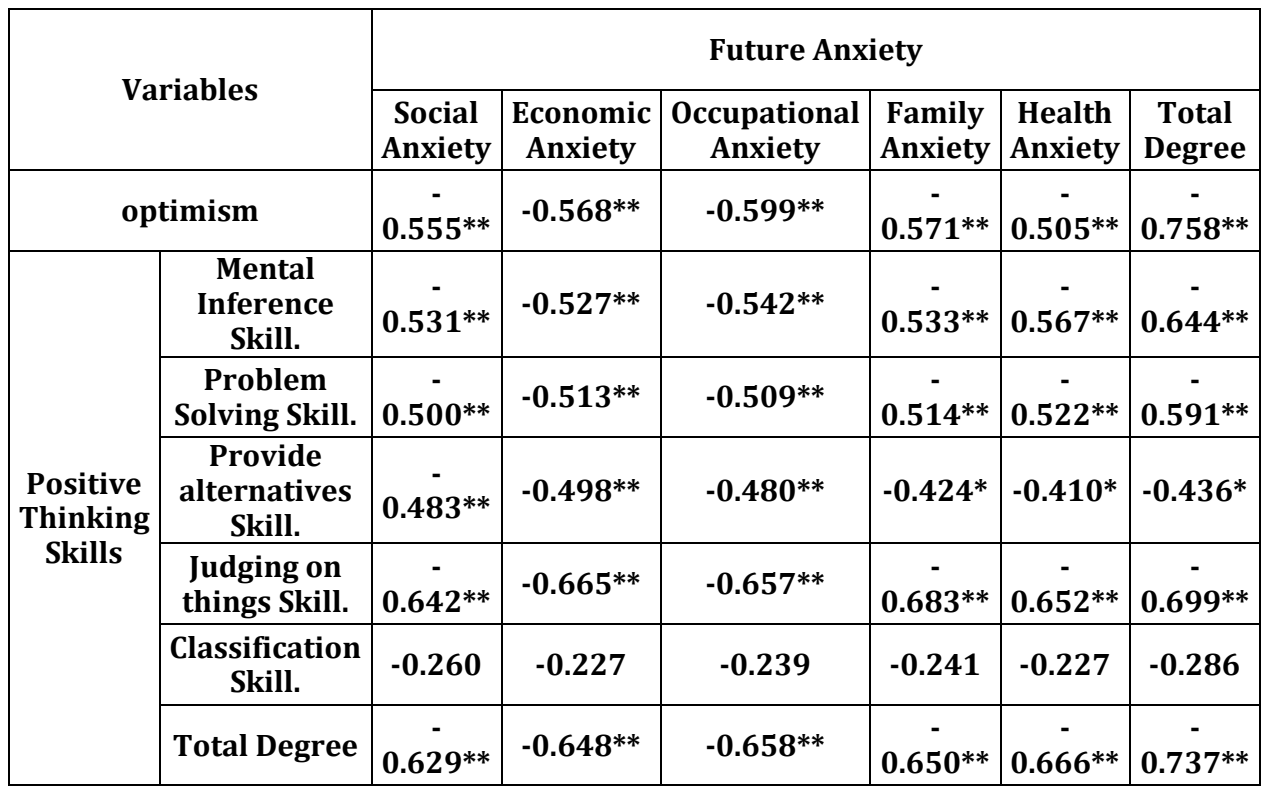

The previous table shows that there are negative significant relationship at the level of significance $(0.01)$ between the future anxiety and all of optimism and positive thinking skills for students in the experimental group after applying of the Development strategy. This result is consistent with the results of several studies and previous research, such as :(Awad,2012),(Jaber,2012),(Husseiny,2011).And the researcher attributed this result to the following reasons, Through the use of self-talk, where the learner can alter the building itself from the outer to the inner building, where strengthens the learner's confidence in himself and his appreciation for the same, And outlook to the future with optimism and reduce the sense of despair and frustration through the psychological climate and 
the creation of appropriate educational problem when you ask and discussed.

\section{Recommendations:}

Researcher recommends the following:

1. Reapply development strategy on other samples from different educational levels of the pre-university education.

2. application of strategy on equality in the different educational levels to see the impact that can have on male and female, and the construction of other strategies that help in the construction of optimism and positive thinking and the face of concern for future students parameters.

3. Teach students how to think positive and make it unusual behavior in their lives, in order to meet future challenges and problems.

\section{Suggestions:}

Researcher suggests know the effect of the development strategy:

1. Some personality traits high for students and low-level grades.

2. The development of thinking skills contemplative stages of education at different levels.

3. Gain moral reasoning, as well as the principles of human rights and applications for Undergraduate Students.

4. Development of divergent thinking skills and increase academic ambition among undergraduate students.

\section{References:}

Abdul-Jawad, Mohamed Said (2014). Positive psychology "what it is and their perceptions theory and future prospects, the publishing house of the Arab EST Psychological Science, No. 34.

Abdul Hakim, Nevin Saber (2009). Practice of behavioral cognitive therapy in the service of the individual to modify 
Allatuaqy behavior for children at risk of delinquency. Journal of the Faculty of Education 26.

Al Ghamdi, Hanan Abdel-Rahman (2000). Mental Health, Cairo, Dar a faker Arabi.

Almhakbh, Muhammad Ahmad (2015). Quality of life predictor of concern for the future, the Faculty of Education and Arts students at the University of the northern border, Journal of Educational Sciences, Volume 10, Issue 1, Saudi Arabia.

Anzi, Youssef Sultan (2007): Impact of training on positive thinking and learning strategies in the treatment of underachievement among fourth graders in Kuwait, Ph.D. thesis unpublished, Cairo, Institute of Educational Studies, Department of Educational Psychology.

Alfy, Dalia Mohamed Fathy (2016). Positive thinking to relieve anxiety among a sample of adolescents with learning difficulties in the development of reading, Ph.D. thesis, Ain Shams University, Graduate Institute for Childhood.

Awad, Aoun (2012). Optimism and pessimism among Gaza's AlAqsa University students in light of some of the changes: Journal of the Islamic University of Educational and Psychological Studies. Volume (20). 2 .s 53-93.

Barakat, Ziad General. (1998). "A Study in the Psychology of Personal: optimism and pessimism and its relationship with some variables related to the student's university." Journal of Calendar psychological, educational, GS 11 and measurement, pp. 55-76

Bashir, S. (2003). Your guide to the statistical program (SPSS), Baghdad: Publications Arab Institute for Training and Research in Statistics.

Bin Mohammad, Mansour. (2015). concerns the professional future and its relationship to optimism and pessimism among secondary school students in Al-Ola, Umm Al Qura University: Saudi Arabia.

Bolte, A., Goschke, T., \& Kuhl, J. (2003). Emotion and intuition:

EVects of positive and negative mood on implicit judgments of semantic coherence. Psychological Science. 
Charles, M-Krumm (2012).L OPTIMISME UNE ANALYSE SYNTHETIQUE Chiers Internationaux de Psychologies' Social .pp103-104.

De Bono, Edward. (2001). Teaching thinking, Dar satisfaction: Damascus Top of Form

De Bono, Edward. (2001). Teaching thinking, Dar satisfaction: Damascus.

Faraj, S.(1991).Factor analysis in behavioral sciences, Cairo: Egyptian Anglo library.

Fredrickson, B. L., Mancuso, R. A., Branigan, C., \& Tugade, M. M. (2000). The Undoing effect of positive emotions. Motivation and Emotion. 24, 237-258.

Fredrickson, B. L., \& Branigan, C. (2001). Positive emotions broaden the scope of attention and thought-action repertoires. Cognition and Emotion, 19(3), 313-332.

Hntol, Ahmed Musa Mohammed (2012) . The effectiveness of psychological counseling program Mitrh to ease future and its impact $\mathrm{Al}$ achievement motivation and the level of ambition among community college students, Jazan University, a PhD thesis, Faculty of Social Sciences, University of Imam Muhammad bin Saud Islamic University.

Husseiny, Atef Massad (2011). Future therapy sense, Cairo, Dar a faker Araby.

Husseiny, Marwa Salah al (2016). Differences among university students depending on the levels of sense of quality of life and their relationship to the quality of life and their relationship to the patterns of positive thinking and negative they have, Master Thesis, Cairo University, Graduate School of Education.

Hsiao \&Et Al (2012). A Study on the Relationship between Thinking Styles (Attitudes) And Collaboration Attitudes of College Students in Taiwan، journal of educational and instructional studies ، Volume: 2 Issue: 2 Article: 07.

Jaber, Ahmed Mohamed (2012). The five major personality factors and concern the future face value LED Palestinian 
university students in Gaza Governorates, Master Thesis, Faculty of Education, Al-Azhar University in Gaza.

Kapka, Sabrina, Baumann, Cédric, Anota, Amélie, Buron Gaelle, Spitz, Elisabeth, Auquier, Pascal, Guillemin, Francis and Mercier, Mariette. (2013). The relationship between traits, optimism and anxiety and health-related quality of life in patients hospitalized for chronic diseases. Health and Quality Life Outcomes, 11 (1) .

Khatib, Jamal. (2003), behavior modification, workers in the psychological, educational and social fields guide, farmer Library, United Arab Emirates

Khouly, Manal Mohammed (2012). Effect based on the improvement of positive thinking skills in decision-making and the level of ambition among female university students academic arrears of study, Journal of Arab Studies in Education and Psychology, No. xxvi Part III -June.

Marlene. G. Cooper (2009). Joon Granuci lesser. OP. PP.153-154. Mashkhy, Ghalib Bin Muhammad Ali (2009). the future anxiety and its relationship with both self-efficacy and the level of ambition among a sample of students from the University of Taif, PhD thesis, Faculty of Education - University of Umm Al Qura.

Mabrok, Ahlam Abdel Azim (2011) . A training program for the development of teaching performance parameter for the student domestic economic specialization in the light of contemporary challenges, the annual conference (Arab VI third countries), in the period from April 13-14.

Madhoun, Manal Omar (2004). Evaluation of home economics curriculum for the students of the primary eighth grade from the viewpoint of the parameters in the schools of the Gaza Strip, unpublished, Master Thesis, College of Education, Islamic University - Gaza.

Mayer, and et all (2007) , Optimisme et pessimism comparatifs consécutifs a 1 exposition a plusieurs messages menaçants: Revue européenne de psychologie appliqué 57, p.23 -35 
Peterson, C. and Seligman, M.E.P. (2004kj). Causal explanations as a risk factor for depression: Theory and evidence. Psychological Review, 91, 347-374.

Saaeda, Jawdat, 2012."Teaching thinking skills," with hundreds of practical examples, the Sunrise House: Amman.

Salem, Amany (2006). The effectiveness of a program for the development of positive thinking among students exposed to psychological pressure in light of Alnozj cognitive, Journal of the College of Education in Ismailia, No. 4. PP 105-169.

Seligman, M. E. P., \& Csikszentmihalyi, M. (2009). Positive psychology: An introduction. American Psychologist, 55(3) , 5-14 .

Suresh Chandra R. Joshi (2013). Positive Thinking: A Powerful Tool to Reduce Social Anxiety of Under Graduate Students Indian Journal of Research Volume: 2 | Issue: 8 | Aug. Shaqoura, Yahya Omar Shaban (2012). almronh Psychological and their relationship good about life at the Palestinian university students in Gaza Governorates, Master Thesis, Faculty of Education - Al-Azhar University of Gaza

Taylor, S. E. (1983). "Adjustment to threatening events: A theory of cognitive adaptation". American Psychologist. 38 (11): 1161-1173. 
